\title{
Karakteristik Lapangan Pekerjaan: Analisis Isi Iklan Lowongan Kerja di Media Surat Kabar
}

\author{
Nanang Martono \\ Dosen Sosiologi FISIP Universitas Jenderal Soedirman Purwokerto, email: \\ nanang_martono@yahoo.co.id
}

\begin{abstract}
Abstrak: Artikel ini merupakan hasil penelitian yang menggambarkan berbagai bentuk lapangan pekerjaan dipublikasikan melalui media surat kabar. Tujuan penelitian ini adalah untuk menggambarkan jenis lapangan pekerjaan serta kriteria calon tenaga kerja yang dibutuhkan yang dipublikasikan di media massa. Penelitian dilakukan menggunakan analisis isi iklan lowongan pekerjaan di harian Kompas, Suara Merdeka dan Radar Banyumas. Hasil penelitian menunjukkan bahwa lapangan pekerjaan yang banyak tersedia adalah pekerjaan sebagai staf kantor dan sales; jenis kelamin yang paling banyak dibutuhkan di pasar kerja adalah perempuan; lapangan pekerjaan lebih banyak membutuhkan calon tenaga kerja lulusan SMA dan diploma; bidang ilmu yang paling banyak dibutuhkan adalah akuntansi dan teknik. Sebagian besar lapangan pekerjaan mengutamakan individu yang mampu mengoperasikan komputer dan menguasai Bahasa Inggris.
\end{abstract}

Kata kunci: iklan, analisis isi, dan lowongan pekerjaan

\begin{abstract}
This article is the result of research that describes the various forms of employment published in newspaper. The purpose of this study was to describe the types of jobs and the criteria required prospective workers published in the mass media. The study was conducted using content analysis of job ad in Kompas, Suara Merdeka and Radar Banyumas. Results showed that jobs available were a job as officer and sales staff; sex most needed in the labor market are women; more jobs require prospective workers and high school diploma graduates; field of science most needed is accounting and techniques. Most of employment priority to individuals who can operate the computer and master in English language.
\end{abstract}

Key words: advertisement, content analysis, and employment.

\section{Pendahuluan}

Salah satu masalah sosial yang dihadapi Indonesia adalah masalah tenaga kerja. Jumlah pengangguran hampir setiap waktu cenderung mengalami kenaikan. Sebagian di antaranya memilih menjadi tenaga kerja di luar negeri, yang kebanyakan adalah perempuan (TKW). Pengangguran ternyata bukan saja berasal dari penduduk dengan tingkat pendidikan rendah, namun diketahui banyak pula sarjana yang sulit mendapatkan pekerjaan.

Jumlah lapangan pekerjaan memang tidak sebanding dengan jumlah pencari kerja. Salah satu indikatornya adalah hampir sebagian besar mahasiswa yang baru menyelesaikan studinya merasa resah bahkan mereka bingung mau ke mana setelah lulus? Ketika suatu perusahaan atau lembaga pemerintah membuka kesempatan kerja, ribuan pelamar hampir selalu membanjiri perusahaan atau lembaga pemerintah yang menyediakan lapangan pekerjaan tersebut. Ibarat gula yang dikerubuti semut, fenomena ini akan lebih menakjubkan lagi ketika pemerintah membuka penerimaan Calon Pegawai Negeri Sipil (CPNS). Puluhan ribu angkatan kerja dapat dipastikan akan mengajukan lamarannya, meskipun formasi yang dibutuhkan hanya segelintir saja.

Jumlah penduduk yang belum memperoleh pekerjaan tidak terbatas pada tingkat pendidikan tertentu saja. Menurut data Badan Pusat Statistik (BPS), 85,75 persen atau sekitar 3,77 juta jiwa orang yang berpendidikan sarjana pada Februari 2008 terserap dalam lapangan pekerjaan, sementara 14,25 persen lainnya menjadi pengangguran terbuka. Pada Agustus 2008, sarjana yang menjadi pengangguran terbuka turun menjadi 12,59 persen dan jumlah sarjana yang mengisi lapangan pekerjaan bertambah menjadi 4,15 juta jiwa orang atau sekitar 87,31 persen. Pada Februari 2009, sarjana yang menganggur kembali meningkat menjadi 12,94 persen, sedangkan yang 
mengisi pekerjaan sebanyak 4,22 juta jiwa atau sekitar 87,06 persen. Pada Agustus 2009, jumlah pengangguran terbuka dari kalangan sarjana kembali meningkat menjadi 13,08 persen, sedangkan sekitar 86,93 persen atau 4,66 juta sarjana telah mengisi berbagai lapangan pekerjaan (dalam Anonim, 2009).

Selain sarjana, peningkatan jumlah pengangguran terbuka juga terjadi pada lulusan Sekolah Menengah Atas (SMA) meningkat sebesar 0,19 persen dibandingkan Februari 2009, sedangkan lulusan diploma (baik D I, D II dan D III) yang menjadi pengangguran terdidik meningkat hingga 2,45 persen dibandingkan Februari 2009. Sementara itu, penurunan pengangguran terbuka justru terjadi pada pendidikan menengah kejuruan. Lulusan Sekolah Menengah Kejuruan yang menjadi pengangguran terbuka pada Agustus 2009 mencapai 14,59 persen atau turun dibandingkan kondisi Agustus 2008 yang mencapai 17,26 persen, sedangkan pengangguran yang lulus Sekolah Dasar (SD) pada Agustus 2009 mencapai 3,78 persen atau turun dibandingkan Agustus tahun lalu yang mencapai 4,57 persen. Demikian pula untuk lulusan Sekolah Menengah Pertama (SMP). Untuk pengangguran terbuka dari lulusan SMP pada Agustus 2009 mencapai 8,37 persen turun bila dibandingkan Agustus 2008 yang mencapai 9,39 persen (Anonim, 2009).

Banyaknya jumlah penduduk yang mencari pekerjaan dapat dilihat melalui Tabel 1.

Tabel 1 menunjukkan status pekerjaan penduduk berusia di atas 15 tahun pada tahun 2007 sampai 2009. Data tersebut menunjukkan bahwa selama tiga tahun, ada kecenderungan penduduk berusia 15 tahun ke atas, sebagian besar bekerja sebagai buruh, karyawan atau pegawai. Sebagian yang lain, pada tahun 2009 adalah berusaha dengan dibantu buruh tidak tetap atau buruh tidak dibayar ( 20,71 persen) dan 17,86 persen adalah sebagai pekerja keluarga yang tidak dibayar. Hal ini mengindikasikan sebagian besar penduduk usia produktif belum memiliki pekerjaan yang layak secara ekonomi, yaitu mampu memenuhi kebutuhan sehari-hari.

Banyak cara yang dilakukan para pencari kerja ini dalam memperoleh informasi lowongan pekerjaan. Cara yang mudah dilakukan adalah dengan membaca iklan lowongan pekerjaan di surat kabar. Surat kabar adalah media yang cukup efektif. Hampir setiap hari di setiap surat kabar ada iklan lowongan kerja ini, baik surat kabar berskala nasional, regional dan lokal. Perkembangan jumlah surat kabar yang beredar, semakin mempermudah penyampaian inoformasi lowongan pekerjaan ini.

Tabel 1 Penduduk 15 tahun ke atas menurut status pekerjaan utama tahun 2007, 2008 dan 2009

\begin{tabular}{|c|l|r|r|r|r|r|r|}
\hline No & \multicolumn{1}{|c|}{$\begin{array}{c}\text { Status Pekerjaan } \\
\text { Utama }\end{array}$} & 2007 (Agst) & \multicolumn{1}{c|}{$\%$} & 2008 (Agst) & \multicolumn{1}{c|}{$\%$} & 2009 (Feb) & $\%$ \\
\hline 1 & Berusaha Sendiri & 20.324 .527 & 20,34 & 20.921 .567 & 20,40 & 20.810 .300 & 19,92 \\
\hline 2 & $\begin{array}{l}\text { Berusaha Dibantu } \\
\text { Buruh Tidak } \\
\text { Tetap/Buruh Tidak } \\
\text { Dibayar }\end{array}$ & 21.024 .297 & 21,04 & 21.772 .994 & 21,23 & 21.636 .761 & 20,71 \\
\hline 3 & $\begin{array}{l}\text { Berusaha Dibantu } \\
\text { Buruh Tetap/Buruh } \\
\text { Dibayar }\end{array}$ & 2.883 .832 & 2,89 & 3.015 .326 & 2,94 & 2.968 .481 & 2,84 \\
\hline 4 & $\begin{array}{l}\text { Buruh/Karyawan/ } \\
\text { Pegawai }\end{array}$ & 28.042 .390 & 28,06 & 28.183 .773 & 27,48 & 28.913 .118 & 27,67 \\
\hline 5 & $\begin{array}{l}\text { Pekerja Bebas di } \\
\text { Pertanian }\end{array}$ & 5.917 .400 & 5,92 & 5.991 .493 & 5,84 & 6.346 .122 & 6,07 \\
\hline 6 & $\begin{array}{l}\text { Pekerja Bebas di } \\
\text { Non Pertanian }\end{array}$ & 4.458 .772 & 4,46 & 5.292 .262 & 5,16 & 5.151 .536 & 4,93 \\
\hline 7 & $\begin{array}{l}\text { Pekerja Keluarga/ } \\
\text { Tak Dibayar }\end{array}$ & $17 . .278 .999$ & 17,29 & 17.375 .335 & 16,94 & 18.659 .126 & 17,86 \\
\hline & \begin{tabular}{l} 
Total \\
\hline
\end{tabular} & 99.930 .217 & 100 & 102.552 .750 & 100 & 104.485 .444 & 100 \\
\hline
\end{tabular}

Sumber: BPS (2009). 
Iklan lowongan pekerjaan di surat kabar merupakan sumber informasi yang relatif mudah diakses. Secara umum ada beberapa informasi yang disampaikan melalui iklan baris ini. Informasi tersebut di antaranya: jenis pekerjaan yang ditawarkan, jenis kelamin pelamar yang diinginkan, kuaifikasi pendidikan, keterampilan lain yang dibutuhkan, mekanisme pengajuan lamaran serta alamat atau nomor telepon perusahaan penyedia lapangan pekerjaan.

Iklan lowongan kerja yang dimuat di surat kabar dalam sehari dapat mencapai puluhan iklan. Namun hal ini tetap saja tidak mampu memenuhi kuota kebutuhan lapangan pekerjaan. Hal ini dikaranekan jumlah lapangan pekerjaan belum mengakomodasi berbagai kriteria pencari kerja. Secara sosiologis, melalui iklan lowongan kerja ini dapat diketahui berbagai kecenderungan umum. Melalui iklan ini, dapat diketahui jenis pekerjaan yang paling banyak ditawarkan, kualifikasi pendidikan (tingkat pendidikan, jurusan, IPK), kualifikasi keterampilan atau kualifikasi tambahan yang lain dan sebagainya.

Permasalahan mengenai ketersediaan lapangan pekerjaan bagi pencari kerja perlu dilakukan. Hal ini disebabkan meskipun jumlah lapangan pekerjaan sangat beragam jenis dan jumlahnya namun tetap belum mampu menampung jumlah angkata kerja. Di sisi lain, pencara kerja mengharapkan bidang pekerjaan yang sesuai dengan keinginannya dan hal ini belum dapat dipenuhi pihak penyedia kerja.

Penelitian ini mengangkat beberapa permasalahan, yaitu: a) Jenis pekerjaan apa yang paling banyak ditawarkan melalui iklan lowongan kerja? b) Jenis kelamin apakah yang paling banyak dibutuhkan di pasar kerja? c) Bagaimanakah kualifikasi pendidikan formal yang dibutuhkan? d) Apakah terdapat perbedaan jenis pekerjaan yang ditawarkan bagi laki-laki dan perempuan? c) Jurusan apa yang paling banyak dibutuhkan? e) Apakah terdapat perbedaan jenis pekerjaan yang ditawarkan bagi lulusan SMP, SMA, diploma dan sarjana? dan f) Apa sajakah persyaratan tambahan yang dibutuhkan selain pendidikan formal?

Penelitian ini bertujuan untuk: a) menggambarkan jenis kelamin yang banyak dibutuhkan di pasar kerja; b) menggambarkan jenis pekerjaan yang banyak ditawarkan melalui iklan lowongan kerja; c) menggambarkan kualifikasi pendidikan formal yang dibutuhkan pasar kerja; d) menjelaskan perbedaan jenis pekerjaan yang ditawarkan bagi laki-laki dan perempuan; e) menggambarkan bidang ilmu yang banyak dibutuhkan pasar kerja; f) menjelaskan perbedaan jenis pekerjaan yang ditawarkan bagi lulusan SMP, SMA, diploma dan sarjana; dan g) mengidentifikasi persyaratan tambahan yang dibutuhkan selain pendidikan formal.

\section{Tinjauan Literatur Pendidikan dan Pekerjaan: Perspektif Sosiologis}

Ada dua perspektif makro dalam sosiologi, yaitu perspektif fungsional dan konflik. Secara fungsional, pendidikan memiliki fungsi positif untuk mempertahankan kesatuan (integrasi) masyarakat. Secara teknis, Durkheim menyebutkan fungsi sekolah untuk menyediakan tenaga kerja lebih disebabkan oleh perkembangan jumlah penduduk yang berimplikasi pada semakin rumitnya pembagian kerja dalam masyarakat (Meighan, 1981). Masing-masing individu diharuskan untuk menempati peran dan posisi dalam masyarakat. Sekolah dalam hal ini berperan untuk membekali individu dalam menempati posisi dan peran-peran tersebut dalam masyarakat.

Parson melihat fungsi pendidikan sebagai mekanisme seleksi sosial (Haralambos dan Holborn, 2004). Untuk dapat menempati posisi sosial dalam masyarakat, individu harus bersaing untuk mendapatkan posisi tersebut. Status pendidikan dalam prosesi ini dianggap sebagai mekanisme atau alat seleksi yang cukup efektif. Setiap individu pasti menginginkan untuk menempati status sosial atas dalam kelompok masyarakat. Akan tetapi, status ini keberadaannya sangat terbatas, tidak semua individu mampu meraih status ini, sementara jumlah individu yang memperebutkan posisi ini jumlahnya tidak terbatas. Oleh karena itu, sistem harus melakukan seleksi untuk memilih individu yang layak menempati posisi atas. Pendidikan dalam hal ini berfungsi sebagai modal sosial bagi individu.

Perspektif ini selanjutnya mengandalkan penjelasan umum akan pentingnya pendidikan dalam masyarakat industri. Ada beberapa proposisi dasar yang dianut, yaitu: 1) Syarat- 
syarat kete-rampilan pekerjaan dalam masyarakat industri secara konstan meningkat karena perubahan teknologi dengan dua proses meliputi: (a) Proporsi pekerjaan yang memerlukan keterampilan rendah menurun dan proporsi yang memerlukan keterampilan tinggi meningkat; dan (b) Ada perbaikan syarat-syarat keterampilan pada pekerjaan yang sama; 2) Pendidikan formal menyediakan pelatihan, baik keterampilan tertentu atau umum, khususnya bagi keterampilan pekerjaan yang lebih tinggi statusnya; dan 2) Syarat-syarat pendidikan bagi pekerja secara konstan meningkat dan makin bertambahnya dalam proporsi yang lebih besar atas populasi diperlukan untuk menghabiskan waktu yang lebih lama di sekolah (Karabel dan Halsey, 1977).

Perspektif fungsional juga menjelaskan adanya stratifikasi atau tingkatan dalam masyarakat yang didasari pada fakta bahwa: 1) Pekerjaan memerlukan sejumlah keterampilan; dan 2) Jabatan tertentu harus diisi oleh orang yang baik, mempunyai kemampuan alamiah, maupun yang mendapatkan pelatihan, hal tersebut, memusatkan perhatian pada syarat keterampilan pekerjaan yang berubah di masa industrialisasi dan memusatkan pada (isi) pengalaman sekolah (Karabel dan Halsey, 1977).

Sekolah dalam hal ini bertugas untuk menyiapkan individu agar menguasai keterampilan yang dibutuhkan pasar kerja. Semakin rumit keterampilan yang dibutuhkan maka akan semakin sempit peluang individu untuk dapat mengaksesnya, hal ini kemudian berimplikasi pada biaya pendidikan.

Perspektif konflik sepakat bahwa pendidikan memang berkaitan erat dengan fungsinya menyediakan tenaga kerja. Namun, fungsi ini telah menyebabkan terjadinya ketidaksetaraan dalam masyarakat. Kelompok bourjuis sebagai kelompok yang mempunyai sumber daya modal, telah melakukan sebagai proses penindasan terhadap kelompok pekerja. Kelompok pekerja hampir selalu berada pada posisi yang tidak menguntungkan, selalu termarginalkan.

Apabila fungsi sekolah dimaknai sebagai mesin yang menghasilkan tenaga kerja, maka yang terjadi adalah sekolah justru semakin melanggengkan posisi kelas bourjuis, dan kemudian kelas ini akan mengeruk keuntungan dari kelas pekerja (yang dihasilkan sekolah) dengan cara eksploitasi. Sekolah hanya menghasilkan individu yang harus tunduk dan patuh pada aturan pemilik modal.

Bourdieu menyebut fungsi pendidikan ini sebagai fungsi reproduksi sosial (Karabel dan Halsey, 1977). Individu dari kelas bawah yang tidak mampu mengakses pendidikan yang lebih tinggi, nantinya hanya akan diposisikan sebagai pekerja kelas bawah, pekerja kasar dengan gaji yang tidak memanusiakan. Sebaliknya, kelompok elit, akan mampu meraih status pendidikan dengan lebih tinggi, sehingga nantinya ia mampu mempertahankan posisinya di dunia kerja. Ketika berada di dunia kerja, orang dari kelompok bawah juga "dipaksa" untuk menyesuaikan dengan habitus kelompok majikan (yang dominan dan kuat). Kelas bawah akan berupaya menyesuaikan gaya hidup, gaya bicara, penampilan serta watak kelas atas. Proses ini disosialisasikan sejak individu mengenyam pendidikan di sekolah. Di sekolah, siswa diajarkan tentang budaya kelas dominan, bagaimana cara bertutur kata yang "layak" agar bisa diterima kerja, bagaimana cara mengatur penampilan, cara bergaya, cara berjalan di depan pelanggan, bagaimana cara berdandan agar lebih menarik pelanggan bahkan bagaimana cara berpakaian yang seksi agar dapat menarik hati pelanggan, semua diajarkan di sekolah untuk memenuhi kebutuhan kelas dominan. Kelompok kelas bawah yang tidak mengenyam pendidikan, tidak akan mampu menjalankan habitus ini, karena habitus mereka berbeda dengan habitus kelas dominan yang menguasai lapangan pekerjaan. Bila mereka tidak mampu menyesuaikan habitus ini, maka tidak akan mungkin mereka menempati posisi strategis dalam pekerjaan (Harker,et.al. 2005; Giddens, 2006). Individu dari kelas bawah hanya mampu menjalani pekerjaan yang sifatnya kasar dan rendah tingkatannya, seperti sopir, tukang batu atau pembantu rumah tangga yang melayani kebutuhan kelas atas.

Dunia sosial menyaratkan adanya kesesuaian antara keahlian yang dimiliki dan pekerjaan. Beberapa pendapat ahli tersebut mengindikasikan bahwa status pendidikan individu akan menentukan status pekerjaannya. Fenomena ini menyebabkan adanya proses reproduksi sosial, artinya seorang individu dari kelas sosial atas 
pada akhirnya akan menghasilkan. Akibat proses ini, status kelas sosial individu akan menentukan pekerjaan apa yang dapat diraih.

\section{Gender dalam Pekerjaan}

Pengertian gender adalah suatu sifat yang melekat pada kaum laki-laki maupun perempuan yang dikonstruksi secara sosial maupun kultural. Menurut Jagtenberg dan D'Alton (1995), "gender and sex are not the same thing. Gender specifically refers to the social meanings attached to biological differences. ... The way we see ourselves and the way we interact are affected by our internalisation of values and assumptions about gender".

Sejarah perbedaan gender (gender differences) antara laki-laki dan perempuan terjadi melalui proses yang sangat panjang, contohnya melalui proses sosialisasi, ajaran keagamaan serta kebijakan negara, sehingga perbedaan-perbedaan tersebut seolah-olah dianggap dan dipahami sebagai kodrat laki-laki dan perempuan. Kaum perempuan adalah pihak yang paling sering dirugikan dalam praktik-praktik gender differences ini, maka konsep bias gender dapat diartikan pembentukan sifat atau karakter laki-laki dan perempuan secara sosial dan kultural yang menguntungkan kaum laki-laki dan merugikan kaum perempuan (Fakih, 2004). Bias gender ini terjadi pada semua bidang kehidupan, termasuk pendidikan dan pekerjaan.

Murid wanita dan pria dalam setiap situasi pendidikan tersebut sama-sama terbuka untuk buku-buku kelas dan bahan-bahan dan sikap guru yang secara halus dapat mempengaruhi penilaian mereka tentang diri mereka sendiri serta masyarakat. Wanita berpartisipasi dalam bidang studi yang berbeda (seperti lebih banyak mengambil ilmu sastra dan ekonomi rumah tangga daripada eksakta). Perempuan dan laki-laki disiapkan untuk menempati posis pekerjaan tertentu. Perempuan karena sifat "kewanitaan" yang lembut, pasif, teliti, rajin sering diposisikan dalam pekerjaan seperti sekretaris, accounting, pramugari, resepsionis, pramuniaga dan sebagainya. Laki-laki dengan sifat maskulinnya diposisikan dalam pekerjaan yang memerlukan kekuatan fisik, seperti teknisi, mekanik, sopir, sales dan pekerjaan lapangan lainnya.

Pembagian kerja berdasarkan jenis kelamin merupakan sebuah image yang merupakan hasil konstruksi gender dalam masyarakat. Peran lakilaki dan perempuan dalam kehidupan sehari-hari berimplikasi pada pembagian kerja dalam dunia kerja. Laki-laki dan perempuan banyak dibutuhkan dalam jenis pekerjaan tertentu. Apabila seorang perempuan menggeluti "profesi laki-laki" maka hal tersebut akan dianggap sebagai sesuatu yang janggal atau tidak pantas. Seorang perempuan yang bekerja sebagai sopir angkot misalnya, akan mendapat persepsi negatif dari masyarakat.

\section{Metode Penelitian Pendekatan Penelitian}

Penelitian ini menggunakan pendekatan kuantitatif dengan metode analisis isi (AI) atau content analysis. Analisis isi didefinisikan sebagai teknik mengumpulkan dan menganalisis ini dari suatu teks. "isi" dalam hal ini dapat berupa kata, arti (makna), gambar, simbol, ide, tema, atau beberapa pesan yang dapat dikomunikasikan (Neuman, 2003).

\section{Obyek Penelitian}

Obyek penelitian ini adalah iklan lowongan pekerjaan yang dimuat dalam tiga surat kabar, yaitu: Kompas (surat kabar nasional), Suara Merdeka (surat kabar regional -Jawa Tengah) dan Radar Banyumas (surat kabar lokal ekskaresidenan Banyumas)

\section{Teknik pengambilan sampel}

Sampel surat kabar diambil secara acak, yaitu surat kabar yang terbit bulan Oktober dan November 2009, masing-masing diambil satu edisi.

\section{Metode Pengumpulan Data}

Metode pengumpulan data yang digunakan adalah metode dokumentasi. Dokumentasi yang dimaksud adalah iklan lowongan pekerjaan yang dimuat dalam surat kabar Kompas, Suara Merdeka dan Radar Banyumas bulan Oktober dan November 2009.

\section{Metode Analisis Data}

Teknik analisis yang digunakan adalah deskripsi diagram batang. Diagram batang merupakan suatu diagram yang menggambarkan suatu distribusi frekuensi dengan bentuk beberapa segi empat. Distribusi frekuensi merupakan suatu 
daftar yang menunjukkan jumlah atau frekuensi setiap kategori data yang ditampilkan. Selain itu, data juga disajikan menggunakan pie chart, yaitu sebuah diagram yang berbentuk lingkaran. Lingkaran tersebut dibagi menjadi beberapa bagian atau daerah yang menunjukkan persentase dari masing-masing kelas. Alat uji statistik yang digunakan adalah modus karena data yang dianalisis dikategorikan berada pada skala nominal.

\section{Hasil Penelitian dan Pembahasan}

Penelitian ini dilakukan dengan menganalisis iklan lowongan pekerjaan yang dimuat di harian Kompas, Suara Merdeka dan Radar Banyumas. Sampel diambil masing-masing satu edisi untuk setiap surat kabar setiap bulannya. Proses penelitian dilakukan selama tiga minggu. Jumlah lapangan pekerjaan yang berhasil dianalisis sebanyak 621 lapangan pekerjaan. Berikut ini disajikan beberapa hasil pengolahan data dari 621 sampel lapangan pekerjaan.

\section{Jenis kelamin}

Variabel jenis kelamin merupakan data yang ditampilkan dalam iklan lowongan pekerjaan. Pihak penyedia lapangan kerja, hampir selalu menyebutkan jenis kelamin calon tenaga kerja yang dibutuhkan.
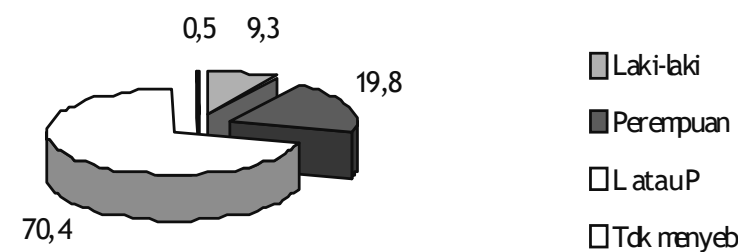

$\square$ Tdk menyebutkan

Gambar 1. Jenis kelamin yang dibutuhkan dalam dunia kerja

Gambar 1 menunjukkan bahwa sebagian besar iklan lowongan kerja, tidak menyaratkan calon tenaga kerja menurut jenis kelaminnya. Hal ini ditunjukkan melalui informasi dalam iklan yang menyebutkan bahwa "dbthkn L/P ut pss....". informasi semacam ini hampir mendominasi iklan lowongan kerja di surat kabar. Apabila dipisahkan, sebanyak 19,8\% lowongan pekerjaan membutuh- kan seorang perempuan dan 9,3\% membutuhkan seorang laki-laki, sisanya $(0,5 \%)$ tidak menyebutkan apakah membutuhkan laki-laki atau perempuan. Hal ini menunjukkan, tenaga kerja perempuan lebih banyak dibutuhkan dalam dunia kerja.

Secara sosiologis, data ini mengisyaratkan bahwa peran perempuan di sektor publik sudah dibutuhkan keberadaanya. Posisi perempuan sudah dianggap sederajat dengan laki-laki, sehingga perempuan banyak dibutuhkan dalam sektor publik.

\section{Jenis pekerjaan}

Informasi berikutnya adalah mengenai jenis lapangan pekerjaan yang dibutuhkan. Berikut ini grafik yang menunjukkan jenis-jenis pekerjaan tersebut dapat dilihat di Gambar 2.

Gambar 2 menginformasikan bahwa, jenis pekerjaan yang banyak ditawarkan melalui iklan lowongan kerja di surat kabar adalah staf kantor atau staf administrasi (sebanyak 32,7\%), sales,

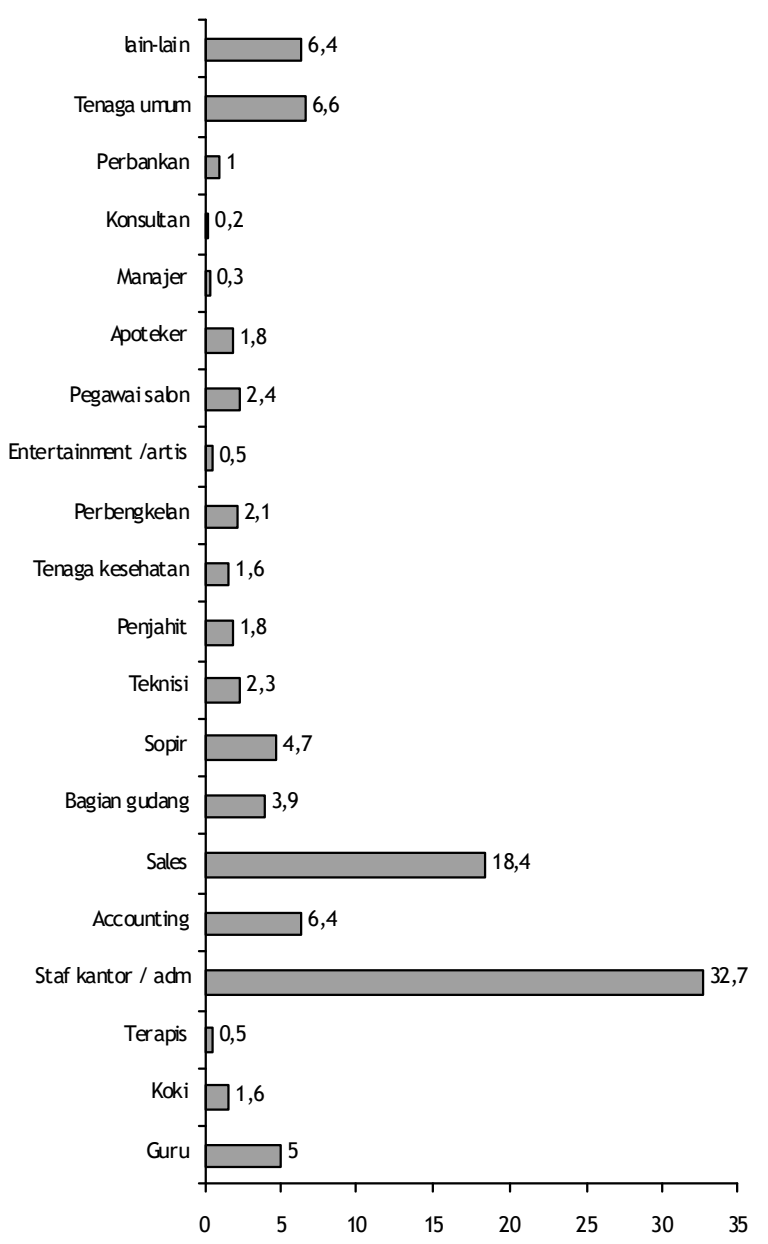

Gambar 2. Jenis pekerjaan yang dibutuhkan 
baik salesman maupun salesgirl, sebanyak $18,4 \%$, kemudian tenaga umum $(6,6 \%)$. Beberapa iklan tidak menjelaskan dengan baik, posisi tenaga umum seperti apa yang ditawarkan. Untuk posisi yang lain, jumlahnya relatif sedikit. Posisi ini meliputi: ABK (anak buah kapal), ahli pijat, TKW, waitrees/er, pembantu rumah tangga, baby sitter, forman lapangan, kasir toko dan operator (tidak disebutkan operator untuk apa). Data ini menunjukkan bahwa posisi pekerjaan yang banyak dibutuhkan, sebagian besar adalah pekerjaan yang berada pada posisi bawahan (sebagai staf) serta tenaga lapangan (sales).
Gambar 3 menjelaskan bahwa sebagian besar lowongan pekerjaan yang diinformasikan di surat kabar, membutuhkan calon tenaga kerja dengan tingkat pendidikan minimal SMA atau sederajat $(63,3 \%)$. Berikutnya adalah tingkat pendidikan diploma (24\%), sarjana $(8,3 \%)$ dan $\operatorname{SMP}(4,4 \%)$.

Apabila dilihat dari jurusan atau bidang ilmu yang dibutuhkan, sebagian besar lowongan pekerjaan menyebutkan "segala jurusan" sebanyak $94,8 \%$. Sebagian kecil lowongan pekerjaan yang ditujukan untuk sarjana, menyebutkan kualifikasi pendidikan formal berasal dari bidang ilmu berikut:

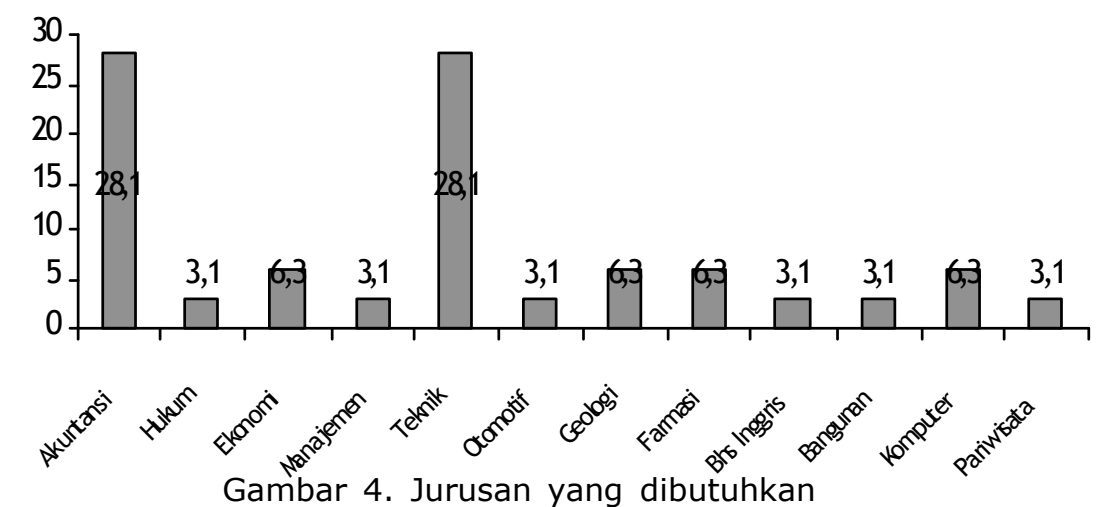

\section{Tingkat pendidikan formal}

Tingkat pendidikan merupakan salah satu hal yang menjadi prasyarat bagi calon tenaga kerja untuk dapat berhasil memperoleh pekerjaan. Hal ini ditunjukkan dengan syarat tingkat pendidikan minimal hampir selalu disebutkan dalam iklan lowongan kerja. Sebagian besar iklan lowongan kerja $(54,4 \%)$ menyebutkan syarat pendidikan formal ini. Syarat pendidikan minimal yang dibutuhkan cukup bervariasi. Berikut ini pie chart yang menunjukkan tingkat pendidikan minimal yang dibutuhkan:
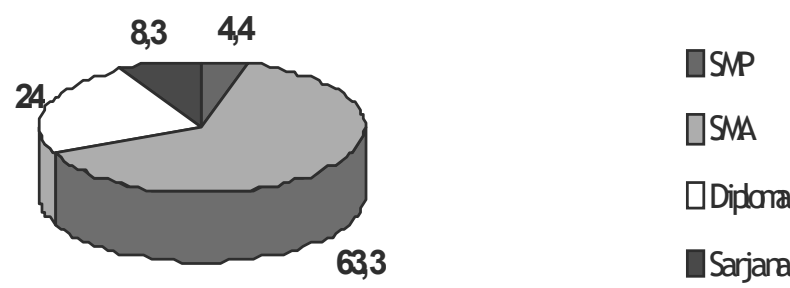

Gambar 3. Tingkat pendidikan yang dibutuhkan
Gambar 4 menunjukkan bahwa ada dua jurusan atau bidang ilmu yang paling banyak dibutuhkan, yaitu Akuntansi $(28,1 \%)$ dan Teknik $(28,1 \%)$. Jurusan lain yang dibutuhkan di antaranya ekonomi, geologi, farmasi dan komputer. Dunia kerja lebih banyak membutuhkan lulusan dari disiplin ilmu yang bersifat terapan atau teknis.

\section{Jenis kelamin dan jenis pekerjaan}

Grafik berikut menjelaskan mengenai hubungan jenis kelamin dengan jenis pekerjaan yang ditawarkan.

Gambar 5 menunjukkan bahwa lapangan kerja tidak terlalu membedakan jenis kelamin. Hal ini dibuktikan dengan persentase lapangan pekerjaan untuk "laki-laki dan perempuan" terlihat lebih dominan. Apabila posisi pekerjaan untuk kedua jenis kelamin diabaikan, maka laki-laki lebih banyak dibutuhkan untuk posisi: sopir $(44,8 \%)$, koki $(20 \%)$, bagian gudang $(16,7 \%)$, teknisi $(14,3 \%)$ dan perbengkelan $(15,4 \%)$. Perempuan 


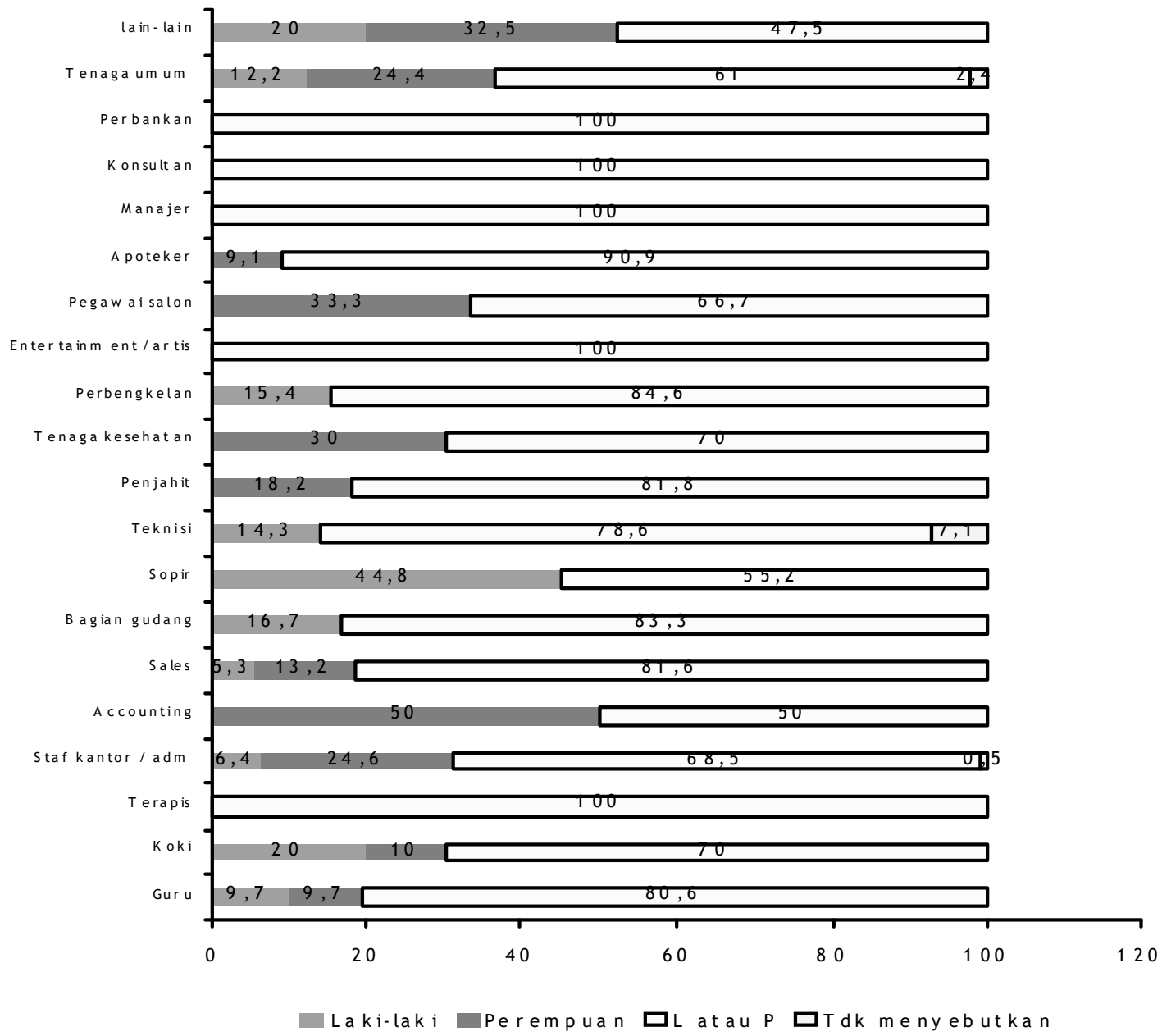

Gambar 5. Jenis kelamin dan jenis pekerjaan yang ditawarkan

lebih banyak dibutuhkan dalam posisi: accounting $(50 \%)$, staf kantor $(24,6 \%)$, pegawai salon $(33,3 \%)$, tenaga kesehatan $(30 \%)$, sales $(13,2 \%)$ dan penjahit $(18,2 \%)$.

Ada hal yang menarik dari data ini, yaitu posisi pekerjaan untuk laki-laki sebagian masih bersifat pekerjaan yang bersifat fisik, kecuali koki. Posisi pekerjaan untuk perempuan masih didominasi pekerjaan yang memerlukan ketelitian (accounting, tenaga kesehatan dan staf kantor), pekerjaan yang memerlukan keterampilan domestik (pegawai salon) serta pekerjaan yang mengutamakan penampilan (sales). Data ini menunjukkan masih adanya pembedan posisi pekerjaan bagi laki-laki (mengutamakan kekuatan fisik) dan perempuan (mengutamakan ketelitian serta penampilan fisik).

\section{Tingkat pendidikan dan jenis pekerjaan}

Secara teoritis, semakin tinggi tingkat pendidikan maka semakin besar peluang seorang individu untuk mendapatkan pekerjaan yang lebih baik.
Gambar 6 menunjukkan hubungan antara tingkat pendidikan dengan jenis pekerjaan yang ditawarkan. Sebagian besar lowongan pekerjaan tidak menyebutkan secara spesifik kriteria tingkat pendidikan calon tenaga kerja yan dibutuhkan. Hal ini dapat diasumsikan bahwa banyak lapangan pekerjaan yang tidak mempermasalahkan latar belakang pendidikan. Data mengenai tingkat pendidikan dan jenis pekerjaan ditampilkan dalam Gambar 6.

Sebagian besar iklan lowongan pekerjaan tidak mencamtumkan tingkat pendidikan calon tenaga kerja yang dibutuhkan. Namun, jika persentase lapangan pekerjaan yang terbuka "untuk umum" tersebut diabaikan, maka ada beberapa hal yang dapat dijelaskan. Individu dengan tingkat pendidikan SMP memiliki peluang yang lebih besar untuk menempati posisi pekerjaan sebagai bagian gudang $(8,3 \%)$, tenaga umum $(4,9 \%)$, sopir $(3,4)$ dan sales $(3,5 \%)$. Seorang Iulusan SMA lebih banyak berkesem- 


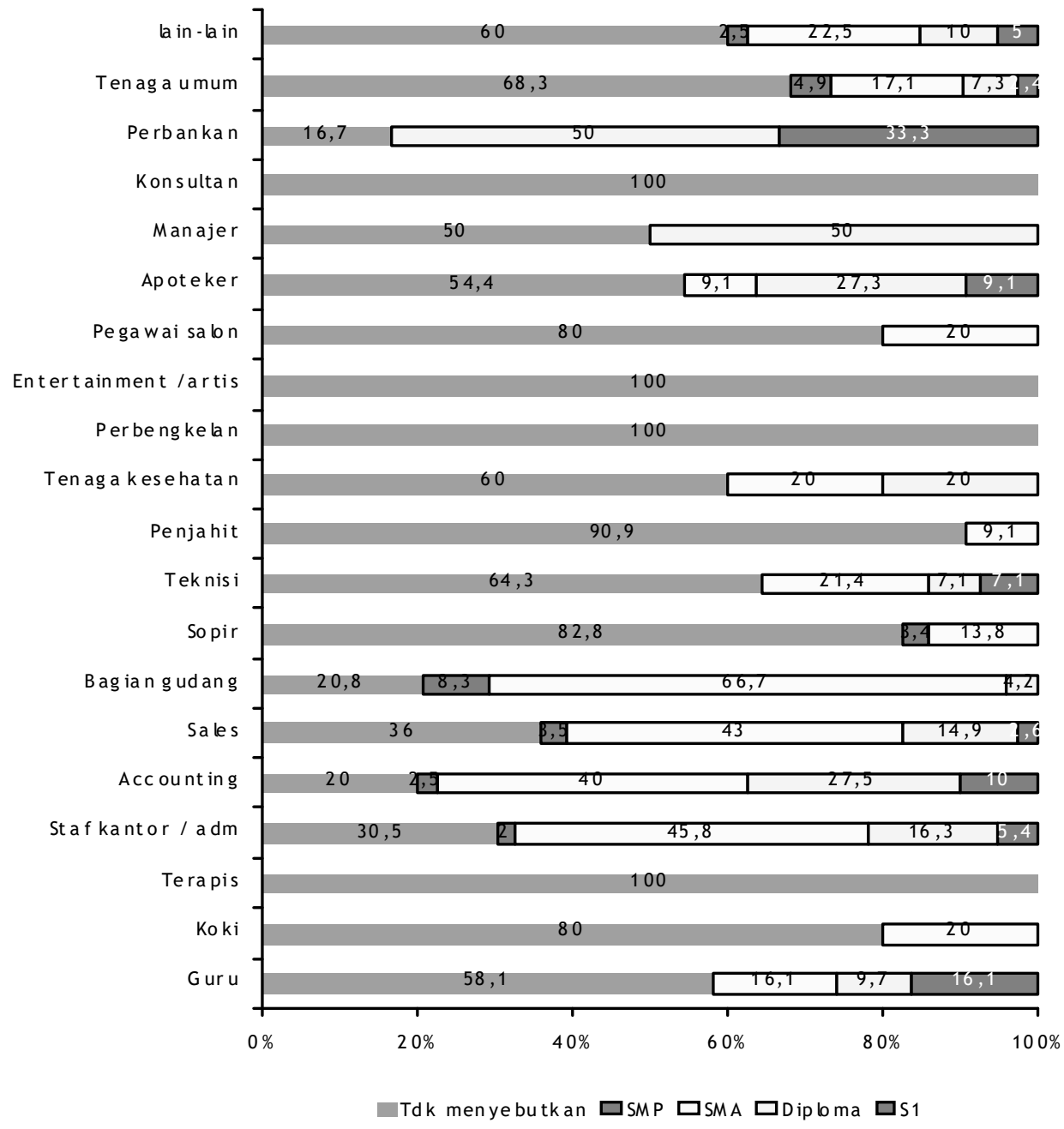

Gambar 6. Tingkat pendidikan dan jenis pekerjaan

patan untuk menempati posisi sebagai bagian gudang $(66,7 \%)$, staf kantor $(45,8 \%)$, accounting $(40 \%)$, sales $(43 \%)$, teknisi $(21,4 \%)$, koki $(20 \%)$, pegawai salon $(20 \%)$ dan guru $(16,1 \%)$. Individu dengan tingkat pendidikan setingkat diploma, memiliki kesempatan bekerja sebagai staf perbankan $(50 \%)$, manajer $(50 \%)$, apoteker $(27,3 \%)$, accounting $(27,5 \%)$ serta tenaga kesehatan (20\%). Posisi pekerjaan bagi sarjana di antaranya adalah perbankan (33,3\%), guru $(16,1 \%)$, accounting $(10 \%)$ dan apoteker $(9,1 \%)$. Data ini memperkuat argumentasi bahwa posisi pekerjaan yang memerlukan keterampilan dan keahlian khusus lebih banyak diperuntukkan bagi individu dengan tingkat pendidikan diploma serta sarajana. Seorang lulusan SMP lebih banyak dibutuhkan dalam posisi pekerjaan yang memerlukan fisik dan lebih banyak berada di lapangan daripada di belakang meja.

\section{Kualifikasi khusus}

Selain kualifikasi formal yang diperoleh melalu jalur pendidikan formal, lapangan pekerjaan juga menyaratkan kualifikasi khusus di luar kualifikasi pendidikan formal.

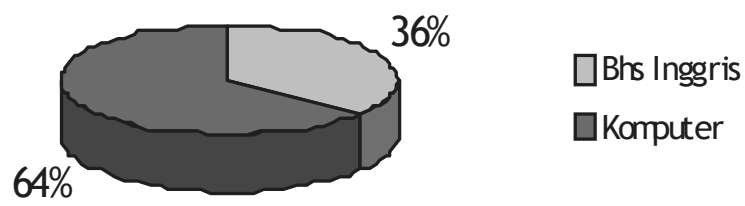

Gambar 7. Kualifikasi khusus yang dibutuhkan

Gambar 7 menunjukkan bahwa ada dua keterampilan yang banyak dibutuhkan dalam dunia kerja, yaitu kemampuan Bahasa Inggris dan penguasaan komputer. Sebagian besar lapangan pekerjaan membutuhkan calon tenaga kerja yang menguasai komputer, sebanyak $64 \%$. Hal ini menunjukkan bahwa penguasaan teknologi 
merupakan salah satu modal dasar bagi individu untuk dapat bersaing di dunia kerja.

\section{Kualifikasi Nonformal}

Selain kualifikasi nonformal berupa kemampuan Bahasa Inggris dan penguasaan komputer, lapangan pekerjaan ternyata juga menyaratkan dimiliki kualitas kepribadian dari calon tenaga kerja. Ada beberapa kualitas pribadi yang banyak menjadi syarat dalam memasuki dunia kerja, yaitu:

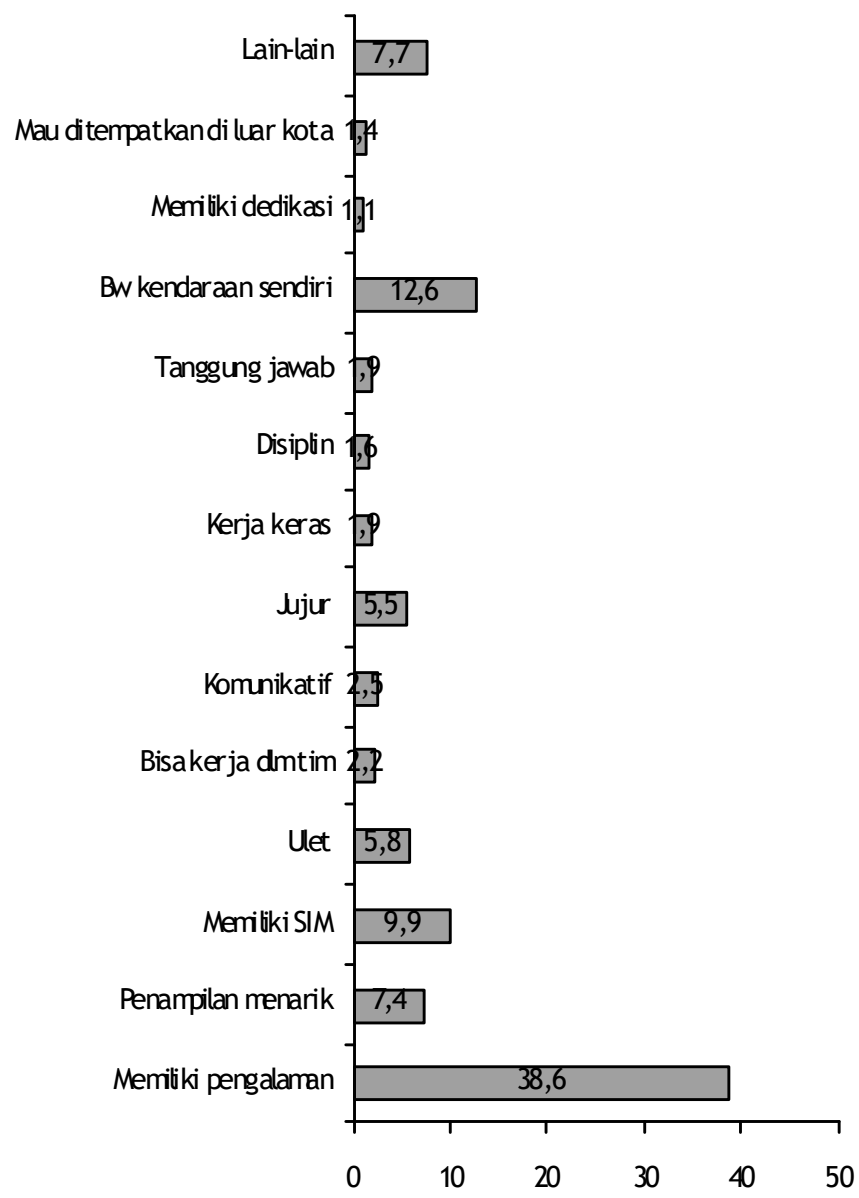

Gambar 8. Kualitas kepribadian yang dibutuhkan (dalam \%)

Gambar 8 menunjukkan ada beberapa kualitas kepribadian yang menjadi prasyarat bagi calon tenaga kerja. Sebagian besar lapangan pekerjaan membutuhkan calon tenaga kerja yang memiliki pengalaman kerja di bidangnya (sebanyak $38,6 \%)$. Kualifikasi yang lain adalah memiliki kendaraan sendiri $(12,6 \%)$ dan memiliki SIM $(9,9 \%)$-syarat ini kebanyakan untuk posisi sales, berpenampilan menarik serta ulet, dan 7,7\% adalah kualifikasi lain yang meliputi: memiliki keahlian memasak, mengemudi mobil, menjahit, inovatif, ramah, kreatif, cinta buku, memiliki motifasi dan integritas yang kuat, rajin, bisa membuat pola, sopan, loyal serta berkelakuan dan kepribadian baik.

\section{Simpulan dan Saran Simpulan}

Mengacu pada hasil penelitian disimpulkan sebagai berikut: 1) Jenis kelamin yang paling banyak dibutuhkan di pasar kerja adalah perempuan $(19,8 \%)$. Akan tetapi sebagian besar lowongan kerja memberikan kesempatan yang sama untuk laki-laki maupun perempuan $(70,4 \%) ; 2)$ Jenis pekerjaan yang banyak ditawarkan melalui iklan lowongan kerja adalah staf kantor $(32,7 \%)$ dan tenaga sales $(18,4 \%) ; 3)$ Lapangan pekerjaan lebih banyak membutuhkan calon tenaga kerja Iulusan SMA $(63,3 \%)$, kemudian diploma, sarjana dan porsi terakhir untuk lulusan $\operatorname{SMP}(4,4 \%) ; 4)$ Laki-laki lebih banyak dibutuhkan untuk posisi: sopir $(44,8 \%)$, koki $(20 \%)$, bagian gudang $(16,7 \%)$, teknisi $(14,3 \%)$ dan perbengkelan $(15,4 \%)$. Perempuan lebih banyak dibutuhkan dalam posisi: accounting (50\%), staf kantor $(24,6 \%)$, pegawai salon $(33,3 \%)$, tenaga kesehatan $(30 \%)$, sales $(13,2 \%)$ dan penjahit $(18,2 \%)$; 5) Ada dua bidang ilmu yang paling banyak dibutuhkan, yaitu Akuntansi dan Teknik (masing-masing 28,1\%). Jurusan lain yang dibutuhkan di antaranya ekonomi, geologi, farmasi dan komputer; 6) Individu dengan tingkat pendidikan SMP memiliki peluang yang lebih besar untuk menempati posisi pekerjaan sebagai bagian gudang $(8,3 \%)$, tenaga umum $(4,9 \%)$, sopir $(3,4)$ dan sales $(3,5 \%)$. Seorang Iulusan SMA lebih banyak berkesempatan untuk menempati posisi sebagai bagian gudang $(66,7 \%)$, staf kantor $(45,8 \%)$, accounting $(40 \%)$, sales $(43 \%)$, teknisi $(21,4 \%)$, koki $(20 \%)$, pegawai salon (20\%) dan guru $(16,1 \%)$. Individu dengan tingkat pendidikan setingkat diploma, memiliki kesempatan bekerja sebagai staf perbankan (50\%), manajer (50\%), apoteker $(27,3 \%)$, accounting $(27,5 \%)$ serta tenaga kesehatan (20\%). Posisi pekerjaan bagi sarjana di antaranya adalah perbankan (33,3\%), guru $(16,1 \%)$, accounting (10\%) dan apoteker $(9,1 \%) ;$ dan 7) Sebagian besar lapangan pekerjaan mengutamakan individu yang mampu 
mengoperasikan komputer (64\%) dan menguasai Bahasa Inggris (36\%). Selain dua keterampilan tersebut, juga memperhatikan kriteria kepribadian, seperti: berpengalaman, memiliki SIM, berpenampilan menarik serta ulet, pandai memasak, mengemudi mobil, menjahit, inovatif, ramah, kreatif, cinta buku, memiliki motifasi dan integritas yang kuat, rajin, bisa membuat pola, sopan, loyal serta berkelakuan dan kepribadian baik.

\section{Saran}

Atas dasar simpulan maka disarankan agar bagi: 1) Calon tenaga kerja atau pencari pekerjaan selain memiliki ijazah pendidikan formal sebaiknya juga memiliki keterampilan tambahan, seperti penguasaan teknologi dan bahasa asing; 2) Lakilaki maupun perempuan memiliki peluang yang hampir sama dalam dunia kerja. Untuk itu, pendidikan mengenai kesetaraan gender harus mulai dilakukan sejak dini agar individu tidak lagi membedakan mana pekerjaan yang sesuai untuk laki-laki dan mana pekerjaan untuk perempuan; 3) Pengembangan kepribadian merupakan agenda yang sangat penting. Proses ini melibatkan lembaga pendidikan sebagai institusi penting dalam proses sosialisasi individu. Untuk itu, pengembangan kepribadian harus dimasukkan dalam kurikulum di sekolah, baik melalui kurikulum formal maupun kurikulum tersembunyi.

\section{Pustaka Acuan}

Anonim, 2009. Sarjana Menganggur Naik 0,49 Persen, situs: http://www.antaranews.com/berita/ 1259665833/sarjana-menganggur-naik-0-49-persen, diakses tanggal 30 Januari 2010

Badan Pusat Statistik. 2009. Penduduk 15 tahun ke atas menurut status pekerjaan utama tahun 2007, 2008 dan 2009. situs: www.bps.go.id, diakses tanggal 30 Januari 2010

Fakih, Mansour. 2004. Analisis Gender dan Transformasi Sosial. Pustaka Pelajar, Jakarta.

Giddens, Anthony. 2006. Sociology Fifth Edition. Polity Press, USA

Haralambos and Holborn. 2004. Sociology: Themes and Perspectives Sixth Edition. Harper Collins Publisher, London

Hacker, Ricard. Cheelan Mahar and Chris Whilkes (ed), 2005. (Habitus x Modal) + Ranah = Praktik Pengantar paling Komprehensif kepada Pemikiran Pieere Bourdieau Jalasutra, Bandung (diterjemahkan dari An Introduction to The Work of Pieere Bourdieau: The Practice Theory oleh Pipit Pieere Bourdieaut Maizier)

Jagtenberg, Tom and D'Alton, Phillip (ed.). 1995. Four Dimensional Social Space Class, Gender, Ethnicity and Nature A reader in Australian social sciences, Second Edition, Harper Educational, Sydney

Karabel, Jerome dan A.H. Halsey. 1977, Power and Ideology in Education, Oxford University Press, New York.

Meighan, Roland. 1981. Sociology Of Educating. Holt Education, New York.

Neuman, William Lawrence. 2003. Social Research Methods: Qualitative and Quantitative Approaches. Boston: Allyn and Bacon 